\title{
Efektivitas antara Umbi dan Daun Tanaman Yakon (Smallanthus Sonchifolius) terhadap Penurunan Kadar Gula Darah Tikus Putih (Rattus Norvegicus) yang Terinduksi Streptozotocin
}

\author{
Thatit Nurmawati ${ }^{1}$, Nawang Wulandari ${ }^{1}$ \\ ${ }^{1}$ STIKes Patria Husada Blitar \\ Email : wulandarinawang23@gmail.com
}

Received 11 May 2018; Accepted 14 May 2018; Published 15 May 2018

\begin{abstract}
ABSTRAK
Komplikasi diabetes mellitus dapat muncul secara akut dan kronis dimana dapat timbul beberapa bulan atau beberapa tahun sesudahnya, sehingga diperlukan penatalaksanaan yang tepat untuk meningkatkan kualitas penderitanya dengan melakukan pengenadalian glukosa darah. Pemanfaatan tanaman yakon dapat menurunkan kadargula darah diantaranya bagian umbi dan daun. Umbi yakon mengandung karbohidrat dan polyphenol, sedangkan daun Yakon mengandung komponen phenol yang terdiri dari chlorogenic, caffeic dan ferulic, dapat memperbaiki sel $\beta$ di pankreas sehingga dapat meningkatkan sekresi insulin. Tujuan penelitian untuk mengetahui perbedaan seduhan daun Yakon dan cairan dari umbi terhadap kadar gula darah tikus putih yang terinduksi streptozotocin. Jenis penelitian ini merupakan jenis penelitian kuantitatif dengan desain Quasy Eksperimental Pre-Post Test With Control Group design. Populasi penelitian adalah tikus putih (Rattus norvegicus) sebanyak 16 ekor. Tikus dibagi menjadi dua kelompok, 8 ekor tikus pertama diberikan cairan dari umbi $100 \mathrm{mg} / \mathrm{kgBB} /$ hari dan 8 ekor tikus kedua diberikan seduhan daun yakon $14 \mathrm{ml} 2$ xsehari, keduanya diberikan selama 3 hari. Pengambilan darah post pada 1 hari setelah perlakuan. Pengukuran kadar gula darah menggunakan Blood glucose test meter Gluco Dr. Analisa data dengan Paired t-test dan Independent t-test. Hasil penelitian menunjukkan ada pengaruh seduhan daun yakon terhadap penurunan kadar gula darah tikus putih dengan $\mathrm{p} 0,000$ dan juga ada pengaruh umbi yakon terhadap penurunan gula darah dengan $\mathrm{p} 0,012$. Dari dua kelompok umbi dan seduhan daun yakon tidak terdapat perbedaan yang bermakna terhadap penurunan kadar gula darah dengan $\mathrm{p}$ 0,294. Pemberian seduhan daun Yakon dan umbi yakon diharapkan dapat menjadi solusi dan pengobatan alternaif dalam menurunkan kadar gula darah.
\end{abstract}

Kata Kunci : Kadar gula, seduhan, umbi, yakon (Smallanthus sonchifolia).

Copyright $\odot 2018$ STIKes Surya Mitra Husada

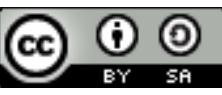

This is an open-acces article distributed under the terms of the Creative Commons Attribution-ShareAlike 4.0 International License. 


\section{PENDAHULUAN}

Diabetes mellitus (DM) merupakan gangguan menahun pada sistem metabolisme dengan ditandai adanya kadar gula darah yang tinggi dan disertai adanya gangguan metabolisme lipid, protein serta karbohidrat (Purnamasari, 2010). Kadar gula tinggi pada kasus DM menjadi masalah, utamanya karena tubuh pasien DM tidak mampu memproduksi atau menggunakan hormon insulin dengan baik untuk memproses makanan (Riskesdas, 2013).

DM menjadi penyebab kematian dalam setiap 10 detik dengan jumlah 3,8 juta jiwa pertahun. Kasus DM di Indonesia menempati urutan keempat setelah India, Cina dan Amerika dengan proyeksi meningkat pada tahun 2030 dari 171 jiwa di tahun 2000 menjadi 366 jiwa. Bersarkan International Diabetes Federation menyebutkan bahwa DM menjadi penyebab kematian urutan ke 7. Data Riskesdas (2013) menunjukkan bahwa proporsi diabetes di Indonesia pada tahun 2013 meningkat hampir dua kali lipat dibandingkan tahun 2007.

Pengobatan pada DM bertujuan untuk menjaga kadar glukosa darah, yaitu dengan memberikan obat (Perkeni, 2015). Namun masih sering kali ditemui pemberian obat yang tidak terkontrol dengan baik dapat berakibat pada kasus hipoglikemi, gangguan pada saluran pencernaan. Selain itu pasien DM mudah sekali mengalami hiperglikemi. Bahkan yang membuat pasien DM semakin tidak berdaya adalah semakin mahalnya harga obat. Pengembangan strategi untuk alternatif pengobatan DM perlu ditingkatkan, salah satunya dengan menggunakan tanaman herbal yang ada di Indonesia untuk mengurangi kasus DM dengan meminimalkan efek samping (Herliana, 2013). Tanaman herbal yang dapat dikembangkan sebagai alternatif pengobatan kasus DM adalah tanaman Yakon (Smallanthus sonchifolius)

Tanaman Yakon terbukti mampu mencegah migrasi polymorphonuclear leucocyites, immunomodulasi, antioksidan dan efek sitoprotektor. Bahkan hasil penelitian mampu membuktikan tanaman Yakon dalam bentuk teh dapat menurunkan kadar gula darah serta meningkatkan kadar insulin pada tikus yang terinduksi bahan diabetik. Pada bagian tanaman Yakon yang lain seperti umbi juga mengandung $\beta$ fruktooligosakarida terbesar dibandingkan dengan tanaman lain. Fruktooligosakarida merupakan gula dengan kandungan kalori lebih rendah dibandingkan gula lainnya (Adifa\&Aditya, 2016). $\beta$ fruktooligosakarida mampu memodulasi sindrom metabolik dan dislipidemi. Fruktooligosakarida merupakan sejenis insulin juga memiliki kemampuan aktivitas prebiotik dengan mengatur metabolisme kolesterol pada proses assimilation melalui penurunan absorbsi kolesterol di usus halus (Grethel, 2013). Tanaman yakon keadaan kering semakin menuju akar kandungan sakarida semakin tingggi. Hal yang sama juga berlaku untuk inulin, fruktose dan glukosa. Namun selama ini yang masiih banyak dilakukan terbatas pada daun Tamanan Yakon.

Penelitian ini bertujuan untuk mengetahui pengaruh kadar gula sebelum dan setelah diberikan umbi atau daun yakon serta mengetahui perbedaan efektifitas antara daun dan umbi tanaman Yakon terhadap kadar gula darah tikus yang terinduksi streptozotocin

\section{BAHAN DAN METODE PENELITIAN}

Penelitian ini merupakan jenis penelitian kuantitatif dengan desain Quasy Eksperimental Pre-Post Test With Control Group design. Penelitian ini menggunakan hewan coba yang telah terinduksi streptozotocin, kelompok akan dibagi menjadi 2 yaitu kelompok pertama akan diberikan umbi tanaman yakon sedangkan kelompok kedua akan diberikan seduhan daun yakon. Besar sampel berdasarkan rumus Federer dengan jumlah sampel yang didapat dalam tiap perlakuan adalah 8 ekor tikus.

Alat yang digunakan untuk mengukur kadar gula yaitu dengan menggunakan gluco Dr. Sebelum pemberian perlakuan hewan diaklimatisasi selama 21 hari dengan selalu diberikan makan dan minum. Kadar gula pertama di cek sebelum hewan coba induksi STZ. Setelah itu STZ diberikan selama 3 hari secara intraperitonial. Perlakuan dengan umbi dan daun tanaman Yakon selama 3 hari dengan cara sonde. Cairan dari umbi diberikan $100 \mathrm{mg} / \mathrm{kgBB} / \mathrm{hari}$ 
sedangan seduhan daun diberikan $14 \mathrm{ml} 2$ xsehari. Pengukuran post test pada hari ke-4 setelah diberikan perlakuan.

Analisa ini digunakan dalam penelitian ini terdiri dari analisis bivariat dan univariat. Dalam analisis univariat dengan menggunakan uji statistik Paired t-test yang bertujuan untuk menguji perubahan kadar gula sebelum dan sesudah pemberian umbi dan daun yakon. Sedangkan untuk membandingkan hasil post test perubahan kadar gula pada kelompok umbi dan daun digunakan analisis data dengan Independen t-test.

\section{HASIL DAN PEMBAHASAN}

Tabel 1.1 Distribusi berat badan tikus putih sebelum dan sesudah perlakuan

\begin{tabular}{ccccc}
\hline \multirow{2}{*}{ Sampel } & \multicolumn{2}{c}{ Umbi } & \multicolumn{2}{c}{ Daun } \\
\cline { 2 - 5 } & Berat pre $(\mathbf{g r})$ & Berat post (gr) & Berat pre (gr) & Berat post (gr) \\
\hline 1 & 260 & 270 & 260 & 260 \\
\hline 2 & 280 & 300 & 370 & 400 \\
\hline 3 & 270 & 270 & 250 & 230 \\
\hline 4 & 300 & 320 & 270 & 260 \\
\hline 5 & 190 & 200 & 290 & 310 \\
\hline 6 & 400 & 440 & 240 & 240 \\
\hline 7 & 260 & 260 & 340 & 380 \\
\hline 8 & 270 & 290 & 320 & 340 \\
\hline
\end{tabular}

Tabel 1.1 Menunjukkan satu per satu berat badan tikus putih sebelum dan sesudah diberikan perlakuan. Berat badan pre perlakuan umbi yakon tertinggi seberat 400gr dan terendah dengan berat $190 \mathrm{gr}$ masing-masing sebanyak 1 ekor tikus. Untuk berat badan post perlakuan umbi tertinggi seberat 440gr dan terendah dengan berat 200gr masing-masing juga sebanyak 1 ekor tikus.

Berat badan pre perlakuan daun yakon tertinggi seberat 370gr sebanyak 1 ekor tikus dan terendah dengan berat $240 \mathrm{gr}$. Untuk berat badan post perlakuan daun tertinggi seberat 400gr dan terendah dengan berat 230gr masing-masing sebanyak 1 ekor tikus.

Tabel 1.2 Distribusi Kadar Gula tikus putih yang terinduksi streptozotocin Sebelum dan Sesudah Diberikan Intervensi pada Kelompok Umbi dan Daun Yakon Tahun 2017

\begin{tabular}{cllccccc}
\hline Kel & Intervensi & N & Mean & St. Deviasi & Min-Max & 95\% CI & $\begin{array}{c}\text { Paired sample } \\
\text { T-Test }\end{array}$ \\
\hline \multirow{2}{*}{ Umbi } & Pre & 8 & 218,13 & 14,237 & $91-236$ & $206,22-230,03$ & 0,000 \\
\cline { 2 - 7 } & Post & 8 & 81,63 & 21,817 & $57-111$ & $63,39-99,86$ & \\
\hline \multirow{2}{*}{ Daun } & Pre & 8 & 254,5 & 14,237 & $181-534$ & $206,22-230,03$ & 0,012 \\
\cline { 2 - 7 } & Post & 8 & 96 & 21,817 & $53-115$ & $63,39-99,86$ & \\
\hline
\end{tabular}

Berdasarkan tabel 1.2 didapatkan rata-rata kadar gula darah keseluruhan sampel sebelum pemberian umbi sebesar $218,13 \mathrm{mg} / \mathrm{dl}$ dimana nilai tertinggi $236 \mathrm{mg} / \mathrm{dl}$ serta nilai terendah $192 \mathrm{mg} / \mathrm{dl}$. Sedangkan rata-rata sesudah pemberian umbi sebesar 81,63 mg/dl dengan nilai tertinggi $111 \mathrm{mg} / \mathrm{dl}$ dan nilai terendah $57 \mathrm{mg} / \mathrm{dl}$. Hasil analisa data dengan Paired sample T-test didapatkan nilai p 0,000, yang berarti ada pengaruh pemberian umbi Yakon (Smallanthus sonchifolius) terhadap kadar gula darah hewan uji tikus putih. Sedangkan tikus yang mendapatkan seduhan daun yakon didapatkan rata-rata kadar gula darah keseluruhan sampel sebelum perlakuan sebesar $254,5 \mathrm{mg} / \mathrm{dl}$ dimana nilai tertinggi 534 $\mathrm{mg} / \mathrm{dl}$ serta nilai terendah $181 \mathrm{mg} / \mathrm{dl}$. Dan rata-rata sesudah perlakuan sebesar $96 \mathrm{mg} / \mathrm{dl}$ dengan nilai tertinggi $115 \mathrm{mg} / \mathrm{dl}$ dan nilai terendah $53 \mathrm{mg} / \mathrm{dl}$. Dari hasil uji statistik didapatkan nilai $\mathrm{p}$ 0,012 yang berarti ada pengaruh kadar gula darah tikus putih sebelum dan sesudah diberi seduhan daun yakon. 
Tabel 1.3 Distribusi Perbedaan Perubahan Kadar Gula tikus putih yang terinduksi streptozotocin Sesudah Diberikan Intervensi pada Kelompok Umbi dan Daun Yakon Tahun 2017

\begin{tabular}{ccccccc}
\hline Variabel & N & Mean & St. Deviasi & Min-Max & 95\% CI & Independent T-Test \\
\hline Post Umbi & 8 & 81,63 & 21,817 & $57-111$ & $63,39-99,86$ & \multirow{2}{*}{0,294} \\
\cline { 1 - 5 } Post Daun & 8 & 96 & 21,817 & $53-115$ & $63,39-99,86$ & \\
\cline { 1 - 3 }
\end{tabular}

Tabel 1.3 Menunjukkan hasil penelitian kadar gula darah setelah perlakuan pada kelompok umbi dan daun yakon. Dari hasil tersebut menunjukkan rata-rata sesudah pemberian umbi $81,63 \mathrm{mg} / \mathrm{dl}$ dengan nilai tertinggi $111 \mathrm{mg} / \mathrm{dl}$ dan nilai terendah $57 \mathrm{mg} / \mathrm{dl}$. Sedangkan rata-rata setelah pemberian daun yakon $96 \mathrm{mg} / \mathrm{dl}$ dengan nilai tertinggi $115 \mathrm{mg} / \mathrm{dl}$ dan nilai terendah 53 $\mathrm{mg} / \mathrm{dl}$.

Hasil uji Independent Sample T-test didapatkan nilai p 0,294 yang berarti tidak ada perbedaan bermakna kadar gula darah tikus putih yang diberi umbi dan yang diberi daun yakon.

\section{PEMBAHASAN}

Analisis perbandingan kadar gula tikus putih yang terinduksi streptozotocin sebelum dan setelah mendapat umbi yakon

Berdasarkan hasil pengolahan data didapatkan rata-rata hasil sebelum perlakuan $218,13 \mathrm{mg} / \mathrm{dl}$ menurun menjadi 81,63 mg/dl. Dari hasil statistik didapatkan $\mathrm{P}=0,000$ dimana $\mathrm{P}<0,05$, dapat disimpulkan bahwa ada pengaruh yang bermakna antara kadar gula darah tikus putih sebelum dan sesudah diberikan umbi yakon.

Umbi tanaman Yakon (Smallanthus sonchifolius) yang masih segar dan diberikan sebanyak $100 \mathrm{mg} / \mathrm{kgBB}$ dengan disonde dapat menurunkan rata-rata kadar gula darah hingga $136,5 \mathrm{mg} / \mathrm{dl}$. Grethel (2013) dalam penelitiannya menyatakan bahwa proses pengolahan dapat mengurangi efek positif dari pangan yaitu menurunkan konsentrasi prebiotik dan FOS. Akar tanaman Yakon (Smallanthus sonchifolius) dapat dikonsumsi langsung ataupun diolah menjadi tepung sebagai bahan dasar kue. Perbandingan hasil penelitian oleh penelitian sebelumnya terkait umbi tanaman Yakon (Smallanthus sonchifolius) segar dan kering tercantum bahwa kandungan gula alami memiliki kalori lebih besar dalam bentuk segar dan memiliki kandungan lemak yang lebih rendah dibanding dalam kondisi kering. Yakon (Smallanthus sonchifolius) dalam kondisi segar memiliki sifat serupa seperti serat makanan di saluran pencernaan sehingga cocok untuk makanan diet (Juciane, 2013).

Ekstrak air dari umbi tanaman Yakon (Smallanthus sonchifolius) bertindak menguntungkan pada parameter biokimia terbukti efektif dalam membalikkan perubahan patologis, terutama dislipidemia dan hiperglikemia yang disebabkan oleh diabetes melitus akibat induksi STZ (Apriyanto\&Sanjaya, 2014). Sehingga berdasarkan teori dan hasil penelitian, air dari umbi tanaman Yakon (Smallanthus sonchifolius) berpotensi menurunkan kadar gula darah tikus putih (Rattus norvegicus).

\section{Analisis perbandingan kadar gula tikus putih yang terinduksi streptozotocin sebelum dan setelah mendapat seduhan daun yakon}

Berdasarkan hasil penelitian terjadi penurunan rata-rata kadar gula darah tikus putih, sebelumnya 254,5 mg/dl menurun menjadi $96 \mathrm{mg} / \mathrm{dl}$. Dari hasil statistik didapatkan $\mathrm{P}=0,012$ dimana $\mathrm{P}<0,05$ sehingga dapat disimpulkan bahwa terdapat pengaruh yang bermakana antara kadar gula darah tikus putih sebelum dan sesudah diberikan seduhan daun yakon.

Menurut Widowati (2010) bahwa didalam daun yakon terdapat phenol yang memiliki efek seperti insulin yaitu dengan menurunkan produksi glukosa dengan menghambat $\alpha$ - 
glukosidase di hepatosit. Enzim $\alpha$-glukosidase seperti maltase, isomaltase, glukomaltase dan sukrase berfungsi untuk menghidrolisis oligosakarida dan disakarida pada dinding usus halus. Inhibisi kerja enzim ini secara efektif dapat mengurangi pencernaan karbohidrat kompleks dan absorbsinya, sehingga dapat mengurangi peningkatan kadar gula darah. Komponen phenol dapat memperbaiki sel $\beta$ di pankreas sehingga dapat meningkatkan sekresi insulin dan meningkatkan sensitifitas reseptor insulin, selain itu enhidrin juga memperbaiki sel $\beta$ dan meningkatkan kadar insulin pada tikus yang terinduksi STZ.

Penurunan kadar gula yang begitu drastis dikarenakan juga oleh aktivitas fisik tikus yang terlalu tinggi, dimana aktivitas tinggi dapat meningkatkan penggunaan glukosa oleh otot. Sintesis gula akan ditingkatkan untuk menjaga agar kadar gula dalam darah tetap seimbang. Ketika tubuh tidak dapat mengkompensasi kebutuhan maka kadar gula tubuh akan menjadi semakin rendah (hipoglikemia). Baroni (2008) menjelaskan bahwa efek hipoglikemi yang ditimbulkan oleh daun yakon yaitu dengan meningkatkan jumlah dan sensitifitas insulin, menurunkan degradasi insulin dan meningkatkan pelepasan insulin sehingga intake gula ke jaringan otot juga akan ditingkatkan. Selain itu penurunan kadar gula begitu drastis disebabkan karena tikus kalah dalam berkompetisi dalam mendapatkan makan karena 1 kandang berisi 2 tikus, hal tersebut akan membuat cadangan karbohidrat di hati bisa menurun secara perlahan sehingga tubuh tidak dapat mempertahankan kadar gula darah yang adekuat. Terlebih lagi dikarenakan pengambilan darah pada posttest dilakukan pada pukul 08.00 ketika tikus belum diberikan makan.

\section{Perbedaan perubahan kadar gula antara kelompok umbi dan kelompok seduhan daun yakon}

Berdasarkan hasil uji statistik Independent Sample T-test didapatkan nilai p 0,294 dimana $\mathrm{p}<0,05$ yang berarti tidak ada perbedaan yang bermakna kadar gula darah antara kelompok umbi dan kelompok daun yakon.

Daun Yakon yang dipilih pada penelitian ini yaitu daun yang diambil pucuknya yaitu 3 daun teratas. Menurut Widowati (2010) pucuk daun Yakon kaya dengan insulin dimana unit-unitnya mengandung fruktosa yang tidak dapat dicerna oleh enzim pencernaan tetapi dapat difermentasi oleh usus besar. Andrianis (2009) mengatakan bahwa pucuk daun Yakon lebih dipilih karena lebih banyak mengandung komponen penting untuk menurunkan kadar gula darah seperti phenolic, chlorogenic dan ferullic. Pucuk daun Yakon sejumlah 7 gram dipotong kecil-kecil dan diseduh. Menurut Andrianis (2009) memotong daun kecil-kecil akan mengakibatkan memar dan dinding sel pada daun menjadi rusak. Cairan sel akan keluar di permukaan daun secara rata. Proses ini merupakan dasar terbentuknya mutu daun yang baik. Sehingga seluruh kandungan senyawa pada daun dapat terurai dengan sempurna.

Pada umbi yakon terdapat dua zat yang berpengaruh dalam penurunan kadar gula darah, yaitu FOS dan polyphenol. Kandungan polyphenol bertanggung jawab atas aktifitas biologis termasuk efek anti-hiperglikemik, agen anti-diabetik serta antioksidan terhadap radikal bebas (Grethel, 2013). Menurut Marinque (2008) kandungan Polyphenol pada umbi tanaman Yakon merupakan komponen kimia yang memiliki sifat antioksidan yang dapat menurunkan stress oksidatif sehingga menurunkan kadar gula darah.

Tanaman Yakon atau daun insulin (Smallanthus sonchifolius) memiliki kandungan polyphenol dan frukotooligosakarida yang tinggi. Kedua kandungan tersebut dapat menurunkan kadar glukosa darah pada diabetes melitus. Oleh karena itu, Yakon dapat digunakan sebagai alternatif agen antidiabetik alami (Adifa\&Aditya, 2016). Kedua kandungan tersebut, yaitu polyphenol dan FOS banyak terkandung dalam akar tanaman Yakon (Smallanthus sonchifolius). 


\section{SIMPULAN DAN SARAN}

\section{SIMPULAN}

Berdasarkan hasil penelitian, dapat disimpulkan bahwa tidak ada perbedaan yang bermakna kadar gula tikus putih antara yang diberikan umbi dan yang diberikan daun yakon.

\section{SARAN}

Perlu dilakukan penelitian lebih lanjut mengenai pengaruh pemberian tanamanYakon (Smallanthus sonchifolia) dengan tidak menggunakan dosis tunggal.

\section{DAFTAR PUSTAKA}

Adifa \& Aditya, M. (2016). Potensi Yacon (Smallanthus sonchifolius) sebagai Agen Antidiabetes. Naskah Publikasi : Majority.

Andrianis, Y. (2009). Pengolahan Teh Hitam. http://www.rumahteh.com. Diakses tanggal 28 Mei 2017 pukul 09.20 WIB.

Apriyanto, D., \& Sanjaya. (2014). Pengaruh Lama Penyimpanan Dan Lama Perebusan Umbi Yakon (Smallanthus sonchifolius) Terhadap Bioavaibilitas Zn Dan Mg. Naskah Publikasi : Jurnal of Chemistry.

Baroni, S., Suzuki-Kemmelmeier, F., Martins, S., Assef, C., Cuman, R.K.N., Aparecida, C. (2008). Effect of crude extracts of leaves of Smallanthus sonchifolius (yacon) on glycemia in diabetic rats.

Depkes RI. (2013). Riset Kesehatan Dasar. Jakarta : Badan Penelitian dan pengembangan Kesehatan Kementrian Kesehatan RI. http://www.depkes.go.id diakses pada _ jumat 3 Februari 2017.

Grethel. (2013). Yacon (Smallanthus sonchifolius) : A Functional Food. Jurnal Nomer 3 Volume 68. Halaman 222-228. Naskah Publikasi: Plants Foods for Human Nutrition.

Herliana, E. (2013). Diabetes Kandas Berkat Herbal. Cetakan I. Jakarta : Fmedia.

Juciane. (2013). Studies of Chemical and Enzymatic Characteristics of Yacon (Smallanthus sonchifolius) and its Flours. Naskah Publikasi : Czech food Science and Technology.

Manrique, I. (2008). Yacon Syrup : Principles and processing. Cetakan ke 2. Peru : Centro International de la Papa (ICIP).

PERKENI. (2015). Konsensus pengelolaan dan Pencegahan Diabetes Melitus di Indonesia. http://www.perkeni.org diakses pada Minggu 5 Februari 2017.

Purnamasari. (2010). Diagnosis dan Klasifikasi Diabetes Melitus. Buku Ajar Ilmu Penyakit Dalam. Jilid III edisi ke-5. Jakarta : EGC.

Widowati, S. (2010). Pemanfaatan Ekstrak Teh Hijau (Camelia Sinensis) Dalam Pengembangan Beras Fungsional Untuk Penderita Diabetes Mellitus. Sekolah Pasca Sarjana Institut Pertanian Bogor. 